\title{
REFERENCES
}

NIELSEN K. E., N"RNBERG P., 1995. TOC content as a test of lysimeters in sandy soils in Denmark. Aarhus Geoscience, Vol. 4, pp.39-43.

TÕNISSON A.,1996. Formation of trophic state in lakelets depending on catchment pecularities. Nordic Hydrological Conference, Vol. 2, pp. 579-588.

\section{СРАВНИТЕЛЬНЫЙ АНАЛИЗ СТРУКТУР СЕТЕЙ УВЕРЕННОСТЕЙ}

\author{
О.И.УЖГА - РЕБРОВ \\ Доктор инженерньг наук \\ Резекненская Высшая пкола \\ Атбривошанас ал. 90, Резекне, Латвия, LV - 4600
}

Задачу нахождения общей модели эмпхрических данньгх обычного называют обучением. Предполагается, что в процессе обучения такая модель может быть построена, используя формальньге методы.

Относительно сетей уверенностей задача обучения может быть разделена на две подзадачи: (1) идентификация топологии сети, (2) обучение численным параметрам. Эти подзадачи связаны между собой. Процедуры обучения параметрам в значительной степени зависят от структуры сети.

Основным типом связи на сетях уверенностей является связь «прхчина следствие». События в родительских узлах являются причиной событий в узлах детях. Естественно, что эта связь носит вероятностный характер. Прицина может инициировать некоторое множество следствий с определенными вероятностямх. Причинные модели являются привлекательньми главным образом потому, что они обеспечивают эффективные структуры для представления эмпирических данньгх.

Основой эффективности причинной модели является ее модульная структура. Отличхтельным признаком модульной структуры является зависимость следствий только от обусловливағощих их причин. Модульность структуры в наибольпей степени характерна для древовидных сетей уверенностей. Для таких сетей каждый промежуточный и конечный узел может иметь только одного родителя. Отсюда следует, что любое локальное множество следствий в узле имеет единственное множество прихин, отражаемых событиями родительского узла. Действия других причин из другнх непрямых предшественников экранируются родительским узлом и оказьвают влияние на следствия только опосредствованно. Это является проявлением известного свойства Маркова: будущие события условно независимы от прошлых событий при известном текущем состоянии окружающего мира. Древовидные сети уверенностей обеспечивают не только экранирование влияний в направлении дуг, но и обеспечнвают разделение влияний для узлов, находящихся на одном уровне иерархии. Знание множества непосредственных причин оставляет промежуточный узел сети независимым от других узлов того же уровня иерархии на дереве. Единственным исключением являются узлы - дети рассматриваемого узла. Но обратное влияние от узлов - детей на родительский узел возникает только в случае реализации одного или нескольких событий в этих узлах. Степень 
этого влияния может быть оценена посредством диагностического вывода. Для случая распространения априорньх вероятностей (предсказательный вывод) события в узлах - детях ни при каких условиях не оказывают влияния на события в родительском узле.

Из вышеприведенного анализа следует, что древовидные сети уверенностей являются наиболее подходяпим средством моделирования приюинных связей между неопределенньми событиями. $\mathrm{K}$ сожалению, не каждая проблемная ситуация может быть моделирована древовидной сетью уверенностей. Предположим, что некоторая проблемная ситуапия моделирована односвязной сетью уверенностей произвольного вида. Существует два варианта действий с такой сетью: (1) преобразовать эту сеть в древовидную форму, (2) решать задачу вероятностного вывода на оригинальной сети. У каждого подхода имеются преимуцества и недостатки. В принцитке существуют хорошо разработанные формальные методы преобразования произвольньгх структур односвязных сетей уверенностей в эквивалентные древовидные структуры. Эквивалентность структур здесь понимается в том смысле, что обе структуры отражают одно и то же общее распределение вероятностей. Переход к древовидной структуре обеспечивает более высокую степень ее модульности. Однако, в процессе такого преобразования могут возникнуть связи между узлами, которые имеют искусственный характер и трудны для интерпретации и оценивания.

Одним из главных приверженцев метода преобразования произвольных структур сетей уверенностей в древовидную форму является Ю.Пирл (Pearl Ј., 1988). Основная причина в том, что разработанный Ю.Пирлом и получивший очень широкое распространение алгоритм распространения вероятностей применим только на деревьях п полидеревьях специальной формы, которые называют деревьями Кима.

Следует подиеркнуть, тто методы перехода к древовидным структурам подвергаются критике со стороны отдельных исследователей (Laskey K.B., 1996) именно из-за искусственного характера такого преобразования.

Если исходная проблемная ситуация моделирована сетью уверенностей произвольного вида, это облегчает дальнейшую работу экспертов по ее оцениванию в том смысле, что дуги и узлы имеют естественную, хорошо понимаемую интерпретацию. $\mathrm{C}$ другой стороны, процесс оценивания затрудняется тем обстоятельством, что возможны множественные причины для некоторьх следствий. В общем случае эксперту всегда знатительно проще оценить условную вероятность следствия при одной причине, чем оценить условную вероятность следствия для множества причин.

Анализируя рассмотренные подходы к формированию и преобразованию структур сетей уверенностей, следует сделать следукощий вывод. Оба подхода имеют преимущества и недостатки. Используя критерий адекватности отражения действительности и интерпретируемости сети экспертами, предпочтение следует отдать сетям произвольного вида без преобразования их в древовидную форму.

\section{ЛИТЕРАТУРА}

1. Pearl J. (1988). Probabilistic Reasoning in Intelligent Systems: Networks of Plausible Inference. Morgan Kaufmann Publisher, Inc., San Mateo, California, $550 \mathrm{p}$. 
2. Jensen F.V. (1996). An Introduction to Bayesian Networks, UCW Press Limited, London, $178 \mathrm{p}$.

3. Laskey K. B. (1996). Model Uncertainty: Theory and Practical Implications. IEEE Transactions on Systems, Man and Cybernetics - Part A: Systems and Humans, Vol. 26, No 3, pp. $340-348$.

4. Laskey K. B. And Lehner P. E. (1994). Metareasoning and the Problem of Small Worlds. IEEE Transaction on Systems, Man and Cybernetics, Vol. 24, No 11, pp. $1643-1652$.

\title{
MAPPING POTENTIAL AREAS OF GROUND SUBSIDENCE IN ESTONIAN UNDERGROUND OIL SHALE MUNING DISTRICT
}

\author{
INGO VALGMA \\ The Mining Institute of Tallinn Technical University, Kopli 82, Tallinn, 10412, Estonia, \\ Internet address htpp://www.ttu.ee/maeinst/ \\ Phone: +372 62038 50, Fax: +37262036 96, E-mail: ingoval@cc.ttu.ee
}

\begin{abstract}
Northeast part of Estonia has been subject to oil shale mining since 1916. Oil shale as main source for power industry in Estonia is mined in amount of 12 million tonnes per year. The underground production rate is about 6 million tomes of the mineral annually. Currently three open casts and six underground mines are operating. In past 6 underground oil shale mines have been closed. Totally 979 million tonnes of rock, including oil shale has been mined underground. Today, about $305 \mathrm{~km}^{2}$ area has 512 million $\mathrm{m}^{3}$ abandoned mine workings in the depth of 10 to $70 \mathrm{~m}$ below the surface. The problem is influence of underground mining and mine workings on ground subsistence and ground- and surface water regime.

Mapping of potential areas of ground subsidence started in the Mining Institute of Tallinn Technical University with MapInfo Professional. GIS is used because of need for locating the tunnels in current geographic situation. As database for digitizing and scanning, available mine maps and drawings are used. Fieldwork is included for recognizing collapse areas in nature. For further analyses, MaphInfo features and additionally, Vertical Mapper are used.

In future groundwater problems will be included in the study. The study is partially supported by Tallinn Technical University by purchasing software MaplInfo. Estonian Mapping Centre has supported the study with making available to use base map of Estonia for reference.
\end{abstract}

\section{Estonian oil shale overview}

Baltic oil shale area (See Figure 1) covers about fifty thousand square kilometers, its oil shale, from Middle Ordovician age is named kukersite oil shale. The Baltic area includes the Estonia and Leningrad deposits and Tapa occurrences, of which the first two are commercially exploited. Estonia deposit is one of the largest 